\title{
Significance of Social Capital in Community Resilience and Performance of Food Security Project in Loima Sub- County, Turkana County, Kenya
}

\author{
Ekiru N. Mark \\ PhD Candidate, School of Open and Distance Learning, \\ University of Nairobi, Kenya \\ Dr. Angeline Sabina Mulwa \\ Lecturer, School of Open and Distance Learning, \\ University of Nairobi, Kenya \\ Prof. Dorothy Ndunge Kyalo \\ Lecturer, School of Open and Distance Learning, \\ University of Nairobi, Kenya
}

\begin{abstract}
This paper examines the influence of social capital on performance of food security projects in pastoral livelihood system. This study used semi-structured questionnaires, interview guides and observation check lists to gather data and information. A total of 491 households were sampled across 11 sub-locations. The study findings showed that social capital has a positive influence $\left(r^{2}=0.2055\right)$, however, the correlation varies depending on the type of social capital. This implied that social capital explained $20.55 \%$ of the variations in performance of food security projects while the other percentage $\mathbf{7 9 . 4 5 \% )}$ is explained by other variables which were not included for this study. In terms of comparison, bridging had the strongest influence $(r=0.496)$, followed by linking $(r=0.142)$ then bonding $(r=0.102)$. The overall $F$ statistic of $F=37.12(p=0.05)$ was statistically significant since at $(p=0.000<0.05)$ hence was suitable to analyze the relationship between social capital and performance of food security projects. The study found out that bonding and bridging social capital were strong while linking social capital was weak in the community. The study concluded that strong bonding and bridging social capital were limited to enhancing short term absorptive and to less extend adaptive capacity of community while the weak linking capital in the study area was associated with low external engagement coupled with lack of resources and increased number of poor people hence impending long-term resilience building to food insecurity.
\end{abstract}

Keywords: Social Capital, Food Security, Food Insecurity, Pastoralist, Project Performance 
Mark, E. N., Mulwa, A. S., \& Kyalo, D. N. (2020) Significance of Social Capital in Community Resilience and Performance of Food Security Project in Loima Sub-County, Turkana County, Kenya. Advances in Social Sciences Research Journal, 7(5) 589-606.

\section{INTRODUCTION}

Performance of food security projects remain one of the major challenges in pastoral communities of Kenya. Studies suggest that social capital is one of the factors that influence the performance of these projects (Uphoff and Wijayaratna, 2000; Flora et al., 2004). Akçomak (2009) define social capital in relation to norms, groups, networks and trust that communities have for productive purposes. Others like Putnam (1993) defines social capital as "features of social organization, such as trust, norms and networks that can improve the efficiency of society by facilitating coordinated actions." Putnam (1993) in his definition attributes social capital to the community, not individuals. Despite the multiplicity of views, there is consensus that social capital encompasses the nature and strength of existing relationships between members, including their skills and abilities that contribute to the development process (Flora et al., 2004). Social capital is thus recognized as a multi-dimensional concept comprising networks of social relations characterized by norms of trust, values and reciprocity.

Flora et al., (2004) categorized social capital into bonding, bridging and linking social capital (Flora et al.,2004). Bonding social capital entails social cohesion within the group and community, based on trust and shared moral values and is reinforced by working together. Bridging social capital on the other hand entails relationships and networks across social groupings, involving coordination or collaboration with other groups. Whereas linking social capital entails the ability of groups or individuals to engage with external agencies and those in positions of influence (Narayan and Pritchett, 1999, Flora et al., 2004). Studies shows that among the pastoralist communities, due to their traditional way of life, the three types of social capital co-exist, but their levels differ (Njuki, et al., 2008).

Pastoralists in developing countries applied different types of informal social support mechanisms for survival during disasters (Omolo and Mafongoya, 2019). The social support systems enhanced mutual assistance through the various forms of social networks. Due to their distinct indigenous social and cultural organization, pastoralists tend to have strong bonding social capital and some bridging capital. However, they often have very little linking capital due to their seclusion from the other larger modern society (Njuki, et al., 2008). These social capital determine the degree in which resilience is enhanced as well as household food security (Moser 2010).

A recent study by USAID (2018) demonstrates that investments in averting humanitarian crises in Kenya would yield savings of up to 30 percent for the international donor community while also protecting billions of dollars of income and assets for the people who would have been most affected by the averted crises. Central to building household capacity to cope with, withstand or bounce back from adverse events and shocks, is the role of social capital. Social capital has for long influenced household and community risk- absorption and adaptation practices which also influenced food security (Hoddinott et al., 2009). Social capital has also been recognized as an important factor in post-disaster recovery (Nakagawa and Shaw 2004).

\section{Statement of the Problem}

Previous literature argues that social capital has a role in the performance of food security projects in rural communities (Degefa, 2009). Food security exists when all people, at all times, have physical, social and economic access to sufficient, safe and nutritious food which meets their dietary needs and food preferences for an active and healthy life according to FAO (2000) definition. The 
performance of food security projects is based on the four dimensions of food security - availability, access, utilization and stability. Availability of food in this case is achieved through production, domestic food stocks, commercial food imports or food aid.

Food accessibility is achieved through purchasing power, financial outlays or access to the necessary resources (Kennedy \& Haddad, 1992). Food utilization is associated with the biological utilization of food: the ability of the human body to convert food into energy which is either used or stored (Keenan et al., 2001). Utilization requires not only an adequate diet, but also a healthy physical environment, including safe drinking water, adequate sanitary facilities and an understanding of proper health care, food preparation, and storage processes. Food stability is the timeframe over which food security is considered (Holben, 2002).

Loima Sub-County an area in which this study was conducted is predominantly occupied by the Turkana pastoralists' community (Watson and van Binsbergen 2008). Turkana residents have experienced the worst of famine and survived the grimmest of droughts. Due to their closely-knit community that is structured along family and clan based bonds and kinships, the strong bonding capital among the Turkana community has always been instrumental in their coping and adaptation to the impacts of recurrent disasters (Omondi, 2013). However, due to long-term marginalization by successive regimes in Kenya, the area has poor linking social capital. This has impended longterm transformation of the community to prevent future impacts thus recurrent cases of hunger, famine and starvation during disasters. For instance, the current Global Report on Food Crises (2020) shows that in Turkana County, the number of acutely food-insecure people in need of emergency food assistance increased throughout from 2019.

Agrawal et al., (2009) as well as Devereux and Getu (2013) recognized that although social networks play important role in improving household food shortage and ensuring survival, they have largely remained invisible in formal policy and programmes towards building food security and building community resilience. In Turkana County for instance, the local community argue that their networking behavior was deliberately ignored in the formulation of relevant livelihood policies in their County (Shackleton et al., 2015). Several studies have shown associations between social capital and development outcomes such as health (Rose, 2000), natural resource management (Pretty \& Ward, 2001), and economic development (Edwards \& Foley, 1998), but few have examined the link between social capital and food security. The current study focused on the role of social capital in encouraging and promoting resilience, in particular examining the role of networks and local-level organizations in food security. Given the increasing role of both state and non-state actors in food security projects in Kenya, results from this study can therefore be instrumental in enhancing the performance and sustainability of the projects.

\section{Hypothesis of the Study}

For this study, the following hypothesis was tested:

1. Ho: Social capital does not significantly influence the performance of food security projects in Loima Sub-County.

2. $\mathbf{H}_{1}$ : Social capital has significant influence on the performance of food security projects in Loima Sub-County. 
Mark, E. N., Mulwa, A. S., \& Kyalo, D. N. (2020) Significance of Social Capital in Community Resilience and Performance of Food Security Project in Loima Sub-County, Turkana County, Kenya. Advances in Social Sciences Research Journal, 7(5) 589-606.

\section{LITERATURE REVIEW}

For this study, understanding of food security concept is based on definition of food security by (FAO, 2000); food security exists when all people, at all times, have physical, social and economic access to sufficient, safe and nutritious food which meets their dietary needs and food preferences for an active and healthy life. Food security has four key dimensions. For this study, performance of food security projects was based on analysis of the four dimensions of food security. Availability of food is achieved through production, domestic food stocks, commercial food imports or food aid. Food accessibility is achieved through purchasing power, financial outlays or access to the necessary resources (Kennedy \& Haddad, 1992). Food utilization is associated with the biological utilization of food: the ability of the human body to convert food into energy which is either used or stored (Keenan et al., 2001). Utilization requires not only an adequate diet, but also a healthy physical environment, including safe drinking water, adequate sanitary facilities and an understanding of proper health care, food preparation, and storage processes. Food stability is the timeframe over which food security is considered (Holben, 2002). For this study food security is assessed with reference to social capital.

Although definition of the concept social capital is still evolving, for this study social capital is understood in terms of norms, groups, networks and trust that communities have for productive purposes (Akçomak, 2009). Social capital exists at different levels; micro/ individual, meso/community as well as macro which is at national or regional level. With reference to these levels, Flora et al. (2004) categorized social capital into bonding, bridging and linking social capital as the core types. Bonding social capital entails social cohesion within the group and community, based on trust and shared moral values and is reinforced by working together. Bridging social capital entails relationships and networks cross social groupings, involving coordination or collaboration with other groups while linking social capital entails the ability of groups or individuals to engage with external agencies and those in positions of influence (Narayan and Pritchett, 1999, Flora et al., 2004).

According to Putman (2000), unlike physical capitals, social capital must be consistently used to grow, and kept active to work for the benefit of the community. Aldrich (2012) affirmed the effectiveness of disaster response depends on understanding of community's social norms, actions based on these norms promote or restrict adaptation actions. In the United States of America for example, Public institutions that traditionally look at efficiency from the resource management and production point of view have begun to recognize social capital as among the essential component to community resilience and adaptation (Hunt et al., 2011).

With reference to food security, there exist three types of social capital that influence food security outcome. Bonding social capital is important for vulnerable and socially excluded individuals to survive through social support especially when relief supplies are distributed but cannot effectively reach to all those in need (Burkley et al., 2011). Higher degrees of bonding social capital can restrict individual freedom and become exclusive barriers to newcomers and outsiders thus restricting access to resources. For instance, after a devastating tsunami in India, it was discovered that an imbalance of social capital caused aid to be distributed unevenly, leaving out many social groups (Aldrich, 2010). 
Excessive bonding social capital can be balanced with greater bridging social capital. Bridging social capital on the other hand connects diverse groups within and outside the community, household and neighborhood (Flora et al., 2004). Bridging social capital is important in the case of nomadic pastoralist communities for management of collective resources in the absence of state presence. In times of disasters, communities use bridging and bonding social capital to sustain food security and mitigate food insecurity caused by disasters. By enhancing partnerships between community organizations and governmental and non-governmental organizations, linking capital enhance the level of access to information and resources (Flora et al., 2004).

The study sought to understand how social capital influences community resilience which in turn is a direct function of food security. Social capital has for long played a role in cushioning communities against shocks as well as in building back better after disasters (Hoddinott et al., 2009). Keck and Sakdapolrak (2013) identify three central capacities in which social capital influence resilience: absorptive, adaptation, and transformation. Absorptive capacity entails the ability of a community to take protective action and 'bounce back' after a shock using predetermined responses to preserve and restore essential basic structures and functions (Cutter et al., 2008; Béné et al., 2012; Oxfam 2017). Adaptive capacity entails the ability of a community to make incremental adjustments, modifications or changes in their way of living in order to continue surviving during and after a disaster functioning (Oxfam 2017). On the other hand, transformative capacity involves long-term development of a community, according to Action Aid (2016), transformative capacity should be enhanced when there is recognition that ecological, economic or social structures keep people trapped in a vicious circle of poverty, disasters and conflict and make the existing system unsustainable.

According to Di Gregorio et al., (2012), bonding and bridging social capital entails more local-level organization which are less formal social networks. Bonding and bridging social capital are therefore limited to enhancing absorptive and to less extend adaptive capacity of community. At some point the local capacity is usually overwhelmed due to limited resources thus rendering communities vulnerable to food insecurity. Di Gregorio et al., (2012) affirmed that bonding and bridging alone may not be sufficient to encourage proactive transformation of communities. Linking social capital is therefore important to enhance external intervention for strengthening of indigenous association and enhance community resilience which at the end influence food security (Tumbo et al. 2013).

In their study on social capital dimensions in household food security interventions in rural Uganda, Haroon et al., (2018) noted that households with bridging and linking social capital characterized by membership in groups and access to information from external institutions tended to be more food secure. However, they established that social capital by itself is insufficient to address food insecurity challenges. They recommended that social capital should be complemented with human capital enhancement.

Kiboro (2018) on his study on impact of social capital on the resettlement of internally displaced persons in Uasin Gishu and Nakuru Counties of Kenya noted that in absence of formal institutional support, internally displaced persons made use of their acquired social capital to resettle. Their social networks served as the primary forms of insurance that they depended on to smooth out the adverse effects of unforeseen exigencies. The study also revealed that norms of reciprocity, values 
Mark, E. N., Mulwa, A. S., \& Kyalo, D. N. (2020) Significance of Social Capital in Community Resilience and Performance of Food Security Project in Loima Sub-County, Turkana County, Kenya. Advances in Social Sciences Research Journal, 7(5) 589-606.

such as being trustworthy and the belief that other people will reciprocate were essential feature of community life among the internally displaced persons.

Morton et al., (2008) on their publication on assessment of rural and urban food pattern showed that knowledge on availability and accessibility of food resources during crisis were more often shared within circles of friends, family, and neighbors in informal settings. Morrow (2013) on his publication on social capital, food security, and resource utilization in a low income population showed that one's experience with food insecurity is a greater predictor of the knowledge development of food resources. In a nutshell, social capital and food security can work both ways as food insecurity can lead to social capital.

\section{Theoretical Framework}

The study is informed by the Social Identity Theory which was first proposed by Tajfel et al., (1979). Social identity theory assumes that we show all kinds of group behavior such as solidarity, within our groups and discrimination against out-groups as part of social identity processes, with the aim to achieve positive self-esteem and self enhancement. From a Social Identity Theory perspective, when community members do not share the predominant traits of the group, they may face negative consequences, such as exclusion or fewer interactions, bias and discrimination (Rutland and Killen, 2015). These negative consequences further impact on the relationship between different households and may negatively impact on the performance of food security projects.

\section{Study Area}

\section{METHODOLOGY}

The study was conducted in Loima Sub-County which is in Turkana County of Kenya. Pastoralism is the main livelihood source in Loima. Pastoralists in Loima use social capital to cope and adapt to drought which is a common phenomenon in the area. However, due to progression in underlying vulnerabilities in the entire Northern Kenya, households have remained exposed to climatic risks (Kareithi, 2010). Figure (1) shows a map of Turkana County with an indication of study area which is Loima Sub-County.

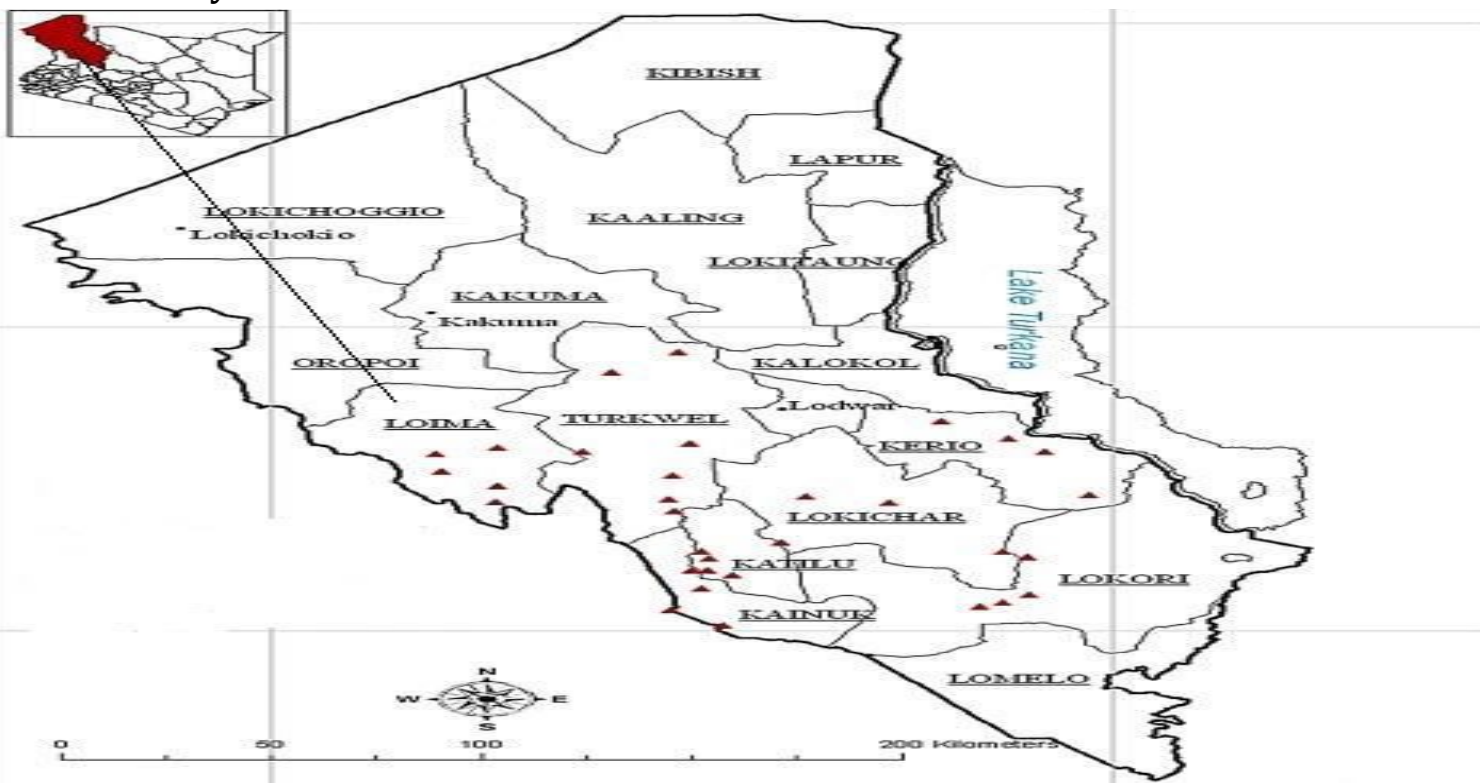

Figure 1: Map of Turkana County showing the study area, (Source: ILRI, 2009). 


\section{Data and Sampling}

Descriptive and correlational research designs were adopted for the study (Thomas, Silverman and Nelson, 2015). Both qualitative and quantitative descriptive research design were used to describe the existing social capital in the community while correlational design was used to measure the relationship between the variables on the performance of food security projects.

Since social capital is multidimensional, manifesting itself through diverse levels of trust, norms, solidarity, and networks, the study employed factor analysis to determine which of the indicators exhibited social capital of a given type -- bonding, bridging or linking (Njuki et al., 2008).

The target population comprised 16,517 households in Loima Sub County which was arrived at by dividing the total population $(229,863)$ of Loima Sub County by 6 which was the average number of individuals per household in Turkana County according to the 2019 census in Kenya. The unit of analysis in this study was the households, their analysis was categorized in reference to the 31 existing sub-locations in the study area. Selection of sub-locations for the study was guided by Slovin's formula which led to random selection of 35\% of 31 sub-locations for the study (Table1).

Table 1: Sample Size for Sub-Locations of Study

\begin{tabular}{|c|c|c|c|c|}
\hline & Sub-location & Population & No. of hh & Sample size \\
\hline 1 & Kotaruk & 3,925 & 654 & 25 \\
\hline 2 & Naipa & 4,502 & 750 & 28 \\
\hline 3 & Turkwel & 19,700 & 3,283 & 88 \\
\hline 4 & Napeikar & 5,500 & 917 & 32 \\
\hline 5 & Lorugum & 11,200 & 1,867 & 54 \\
\hline 6 & Nadapal & 25,000 & 4,167 & 99 \\
\hline 7 & Kawalathe & 4,000 & 667 & 26 \\
\hline 8 & Lochor-edome & 4,500 & 750 & 28 \\
\hline 9 & Lochor-ekuyen & 4,000 & 667 & 26 \\
\hline 10 & Lochor-alomala & 6,907 & 1,151 & 27 \\
\hline 11 & Lokiriama & 9,865 & 1,644 & 49 \\
\hline & & $\mathbf{9 9 , 0 9 9}$ & $\mathbf{1 6 , 5 1 7}$ & $\mathbf{4 9 1}$ \\
\hline
\end{tabular}

A multi-stage sampling strategy was used to select the sample from the 11 sub-locations selected. Sample size for the households was obtained using Slovin's formula denoted by the population size and the acceptable margin of error of 0.05 as indicated in the following formula:

Where:

$$
\text { Sample Size }(\mathrm{n})=\frac{N}{1+N e^{2}}
$$

$$
\begin{aligned}
& n=\text { Number of samples } \\
& \mathrm{N}=\text { Number of Households } \\
& \mathrm{e}=\text { Marginal error }(0.05)
\end{aligned}
$$

Calculating the sample size,

$$
\text { Sample Size }(\mathrm{n})=\frac{16,517}{1+16,517 * 0.05^{2}}=390.54 \cong 391
$$

An extra 100 households were added to make the sample size to be 491 so as to take care of the sampling errors. Simple random sampling strategy was used to select 491 households for the study. 
Mark, E. N., Mulwa, A. S., \& Kyalo, D. N. (2020) Significance of Social Capital in Community Resilience and Performance of Food Security Project in Loima Sub-County, Turkana County, Kenya. Advances in Social Sciences Research Journal, 7(5) 589-606.

Purposive sampling was employed to identify key informant interviewees who in this case are the project managers Mertens (2014). The main instruments of data collection for the study were semistructured questionnaires, interview guides and observation check lists.

\section{Data Analyses}

To establish performance of food security projects, the four standard components of food security were analyzed. A three-tier food consumption score on a scale of poor (1-21), borderline (21.5-35) and acceptable ( $>35)$ was used to analyze food access. Dietary diversity index was used to analyze food utilization and the nutritional value of food consumed.

The research instruments were checked for validity to ensure that they measure correctly the intended constructs (Heale and Twycross, 2015). In this study the reliability of the instruments was taken at Cronbach's alpha coefficient of 0.8, since it is greater than 0.7. Descriptive analysis was used to understand non-parametric data while inferential statistics were used to test the hypotheses which were further used to generalize the findings. Linear regression model was developed to establish relationships between the dependent and independent variables on social capital and food security projects in the study area. The model equation is illustrated below.

Where

$$
\begin{gathered}
\text { Social capital }=\mathrm{f}(\text { food security projects }) \mathrm{Y}=\mathrm{f}(\mathrm{X} 1, \boldsymbol{\varepsilon}) \\
\mathrm{Y}=\beta \mathrm{o}+\beta 1 \mathrm{X} 1+\boldsymbol{\varepsilon}
\end{gathered}
$$

$\mathrm{Y}=$ Performance of food security projects $\mathrm{X} 1=$ Social capital

$\beta o=$ Constant term

$\beta 1=$ Beta Coefficient

\section{Types of Social Capital}

RESULTS

Table 2 shows the types of social capital and their descriptive characteristics. It was observed that the majority of the sampled households indicate bonding social capital $(90.9 \%)$ which entailed horizontal links between family members, close friends and relatives was the most common type of social capital, followed by bridging capital (35.4\%) which was conceptualized as a network that connects members across communities, while linking capital which connects social networks vertically with some form of authority in the social sphere existed the least with $25.8 \%$ of the respondents.

Table 2: Type of Social Capital

\begin{tabular}{|c|c|c|c|}
\hline Type & N & Frequency & Percentage \\
\hline Bonding & 418 & 380 & 90.9 \\
\hline Bridging & 418 & 148 & 35.4 \\
\hline Linking & 418 & 108 & 25.8 \\
\hline
\end{tabular}

In order to understand the dimensions of social capital in the community, a 5-point Likert scale ranging from $5=$ Strongly Agree, $4=$ Agree, $3=$ Neutral, $2=$ Disagree, and lastly $1=$ Strongly Disagree was used to analyze statements touching on variables on social capitals (Table 3 ). 
Table 3: Statements on Dimensions of Social Capital in the community

\begin{tabular}{|c|c|c|}
\hline Statements & Mean & Standard deviation \\
\hline I belong to social groups & 4.15 & 0.92 \\
\hline I trust my neighbors for support & 3.29 & 1.34 \\
\hline I feel safe in the village & 4.38 & 1.13 \\
\hline We stand for each other in times of need & 4.48 & 1.08 \\
\hline I relate well with fellow community members & 3.47 & 1.39 \\
\hline I can ask my friends for help & 3.93 & 1.21 \\
\hline We communicate freely and empower each other & 3.63 & 1.35 \\
\hline Our community is hospitable & 4.07 & 1.12 \\
\hline I can leave my children with a neighbor when going to the market & 3.44 & 1.17 \\
\hline We talk about problems affecting the community & 4.38 & 1.09 \\
\hline Composite mean & $\mathbf{3 . 9 1}$ & $\mathbf{0 . 4 3}$ \\
\hline
\end{tabular}

Results from Table 3 shows that majority of the community members belong to a social group indicating they lived in harmony together. The respondents were generally not sure whether they trusted their neighbors or not. Feeling safe in the village, standing with each other in times of need and talking to each other about problems affecting the community gave strong means of 4.38(1.13), 4.48(1.08) and 4.38(1.09) respectively, which indicates that respondents agreed with those statements. Statements relating to good relationship with community members and being capable of leaving children with a neighbor when going to the market returned a mean of 3.47(1.39) and 3.44(1.17), showing that the respondents were neutral in their responses. The mean of social capital, computed after putting all the constructs together was found to be 3.91 and a standard deviation of 0.43 , this shows that the respondents agreed with most of the statements regarding social capital.

To understand the contribution of social capital towards food security in the study area, the study sought to establish the contribution of knowing each other and associated social support mechanisms in the community towards food security. The results are as presented in Table 4.

Table 4: Social Capital Contribution to Food Security

\begin{tabular}{|c|c|c|c|}
\hline Social Variables that influenced food security & $\mathbf{N}$ & Frequency & Percentage \\
\hline Hospitable intercommunity and cross border migration & 418 & 351 & 84.0 \\
\hline Market access and trading & 418 & 190 & 35.4 \\
\hline Sharing of community resources & 418 & 133 & 31.8 \\
\hline Sharing of information and knowledge & 418 & 181 & 43.3 \\
\hline
\end{tabular}

From (Table 4) 84\% of the respondents believe that knowing each other leads to hospitable intercommunity and cross border migration which can enable people to move from one area to another in times of disaster, hence helping reduce food insecurity. Market access and trading was also seen as being important by $35.4 \%$ of the respondents, sharing of community resources and sharing of information and knowledge between communities and individuals were also important with $31.8 \%$ and $43.3 \%$ respectively. 
Mark, E. N., Mulwa, A. S., \& Kyalo, D. N. (2020) Significance of Social Capital in Community Resilience and Performance of Food Security Project in Loima Sub-County, Turkana County, Kenya. Advances in Social Sciences Research Journal, 7(5) 589-606.

Analysis of trends of social networks in Loima showed that the social networks among the community members were getting weaker. The major cause of weakening of the social networks include: politicization and segregation (79.4\%), erosion by modern ways of life (54.3\%), establishment of boundaries (34.4\%). Other reasons given include: Insecurity and migration.

Some social norms and beliefs were impending food security initiatives in Loima Sub-County, they include: eating habits and food preferences of the community members, polygamous type of marriages, overreliance on pastoralism as well as overdependence on traditional seers and prophets to predict weather and foretell what the community might experience in the near future (Table 5).

Table 5: factors that influenced erosion of social capital

\begin{tabular}{|c|c|c|c|}
\hline & N & Frequency & Percentage \\
\hline Erosion by modern ways of life & 418 & 227 & 54.3 \\
\hline Establishment of boundaries & 418 & 144 & 34.4 \\
\hline Migrations & 418 & 140 & 33.5 \\
\hline Insecurity & 418 & 141 & 33.7 \\
\hline Politicizations and segregation & 418 & 332 & 79.4 \\
\hline
\end{tabular}

\section{Performance of Food Security Projects}

The major type of projects that were implemented in Loima Sub County to cushion the food insecure are short-term projects as indicated by $66.63 \%$ of the study respondents. The short term projects included, relief food distribution, vouchers, and cash distribution. Development projects were the second popular projects in the area of study given by $21.28 \%$, they included; natural resources management, income generation projects, skill and knowledge building and youth and women empowerment. Medium to long term projects accounted for $10 \%$ of the total respondents, these projects were; assets creation, savings and loans schemes, and irrigation schemes. The remaining $1.79 \%$ of the respondents indicated that no food insecurity alleviation projects were implemented.

To analyze the performance of food security projects, the four components of food security were assessed, they include: food availability, food accessibility, food utilization and food stability. It was assumed that if the respondents are food secure then the food security projects would be considered to be successful.

On food availability majority of the respondents indicated that the functionality of the local food market was important in availing food in the study area. Food in the local market were mainly imported from other Counties in Kenya and bordering agricultural rich countries such as Uganda. Foods available in the local market included: cereals, vegetables, oil, sugar, dairy products, poultry products, as well as meat. However, insecurity, resource based conflicts and cattle rustling limited access to market. During drought availability of some products such as milk was altered.

On food access, the food consumption score which is categorized in terms of: poor (1-21), borderline (21.5-35) and acceptable ( $>35)$ showed that $48.97 \%$ of the households in Loima Sub- County have poor food consumption status, $29.23 \%$ have borderline consumption status while $21.79 \%$ had acceptable food consumption status. The result is attributed to overreliance on pastoralist form of 
livelihood which is affected by shocks such as drought, flash floods, insecurity, conflicts and pests and diseases. Such shocks affect availability and access to nutritious food.

With reference to food utilization, the dietary diversity score showed that cereals and oil formed the main part of households' staple daily diet (49\%), fruits, vegetables and fish were least consumed (12\%). Other food consumed in the study area include dairy products, and meat (39\%). Although pastoralism was an important livelihood in the study area, recurrent droughts had led to death of livestock making the community to rely on relief food which in most cases was in form of cereals and oil. The harsh climatic condition does not favour crop agriculture thus low consumption of fruits and vegetables by the respondents.

To understand the coping strategies to food insecurity in the study area, five statements on performance of food security were rated on a scale ranging from never (1) to always (5) as shown in the Table 4. On average the respondents indicated that sometimes they had to sleep hungry at night within the past one month (mean=2.65, $\mathrm{SD}=1.13$ ), they worried that their household would not have enough food (mean=3.05, $\mathrm{SD}=1.13$ ), their household had to dispose of productive assets to meet basic needs such as food (mean=2.80, $\mathrm{SD}=1.40$ ), their household relied on food assistance from external sources (mean=3.14, $\mathrm{SD}=0.93$ ) and they relied on market as the main source of food (mean=3.32, $\mathrm{SD}=1.01)$.

Table 6: Analysis of Coping Strategy

\begin{tabular}{|c|c|c|}
\hline Statements & Mean & $\begin{array}{l}\text { Standard } \\
\text { Deviation }\end{array}$ \\
\hline $\begin{array}{c}\text { In the past month, how often did you or any HH member go to sleep at night } \\
\text { hungry? }\end{array}$ & 4.15 & 1.13 \\
\hline $\begin{array}{l}\text { In the past month, how often did you worry that your HH would not have } \\
\text { enough food? }\end{array}$ & 4.05 & 1.13 \\
\hline $\begin{array}{l}\text { In the past one month how often has your household disposed of productive } \\
\text { assets to meet basic needs such as food? }\end{array}$ & 3.30 & 1.14 \\
\hline $\begin{array}{l}\text { In the past one month how often has the household relied on food assistance } \\
\text { from external sources? }\end{array}$ & 4.14 & 0.93 \\
\hline $\begin{array}{l}\text { In the past one month how often do you rely on market as the main source of } \\
\text { food }\end{array}$ & 3.32 & 1.01 \\
\hline Composite mean & 3.792 & 1.068 \\
\hline
\end{tabular}

Some of the other coping strategies to food insecurity mentioned by the respondents include: using less expensive foods (98.3\%), borrowing and relying on relatives and friends (55.6\%). Equally majority of the households reduced meals eaten in a day 1-2 days per week to cope with food insecurity (48.8\%).

Major impediments towards food security in Loima Sub-county included climate shocks and natural hazards, as indicated by $60.6 \%$ of the study respondents, conflicts and insecurity forms the second most popular cause of food instability with $26.5 \%$ of the respondents, while economic crisis recorded $12.3 \%$ of the respondents.

\section{Correlation between social capital and performance of food security projects}

To determine the direction and magnitude of the relationship between social capital and performance of food security projects in Turkana County, a Pearson correlation analysis and 
Mark, E. N., Mulwa, A. S., \& Kyalo, D. N. (2020) Significance of Social Capital in Community Resilience and Performance of Food Security Project in Loima Sub-County, Turkana County, Kenya. Advances in Social Sciences Research Journal, 7(5) 589-606.

mathematical regression model was used. Social capital was a composite of three indicators: Binding, Bridging and Linking (Table 7).

Table 7: Correlation between social capital and performance of food security projects

\begin{tabular}{|c|c|c|c|c|}
\hline \multicolumn{2}{|c|}{} & Binding & Bridging & Linking \\
\hline Performance of food & Pearson Correlation & $0.2246^{*}$ & $0.3753^{*}$ & $0.2249^{*}$ \\
security projects & Sig. (2-tailed) & 0.000 & 0.000 & 0.000 \\
\hline & $\mathrm{N}$ & 420 & 420 & 420 \\
\hline
\end{tabular}

The variables of social capital were statistically correlated with performance of food security projects. Though the correlations are weak, they are positive, implying performance increases with an increase in levels of bonding, bridging and linking among the social communities. In terms of influence, bridging and linking seems to have more influence on performance of food security projects as compared to bonding.

To capture causation link, a regression analysis was done. The regression model for social capital and performance of food security projects coincides with the null hypothesis (H0): Social capital does not significantly influence the performance of food security projects. Using ordinary least squares model, the data was regressed, and results presented in Table 8.

Table 8: Summary of the Regression model on Social Capital and Performance of Food Security Projects

\begin{tabular}{|c|c|c|c|c|c|}
\hline \multicolumn{6}{|c|}{ Model Summary } \\
\hline Model & \multicolumn{2}{|c|}{$\mathrm{R}$} & R square & $\begin{array}{l}\text { Adjusted R } \\
\text { Square }\end{array}$ & $\begin{array}{l}\text { Std. Error of the } \\
\text { Estimate }\end{array}$ \\
\hline & 0.2 & & 0.2111 & 0.2055 & 0.73926 \\
\hline \multicolumn{6}{|c|}{ Predictors: (Constant) Bonding, Bridging, Linking } \\
\hline \multicolumn{6}{|c|}{ ANOVA } \\
\hline Model & $\begin{array}{c}\text { Sum of } \\
\text { squares }\end{array}$ & Df & Mean Square & $\mathrm{F}$ & \\
\hline Regression & 60.85 & 3 & 20.28 & 37.12 & 0.000 \\
\hline Residual & 227.35 & 416 & 0.55 & & \\
\hline Total & 288.20 & 419 & & & \\
\hline \multicolumn{6}{|c|}{$\begin{array}{l}\text { Dependent Variable: Performance of Food Security Projects } \\
\text { Predictors: (Constant) Bonding, Bridging, Linking }\end{array}$} \\
\hline \multicolumn{6}{|c|}{ Coefficients } \\
\hline Model & \multicolumn{2}{|c|}{$\begin{array}{c}\text { Standardized } \\
\text { Coefficients }\end{array}$} & $\begin{array}{c}\text { Unstandardized } \\
\text { Coefficients }\end{array}$ & & \\
\hline & B & Std. Error & Beta & $\mathrm{t}$ & Sig. \\
\hline (Constant) & 3.633 & 0.111 & & 32.720 & 0.000 \\
\hline Bonding & 0.102 & 0.061 & 0.193 & 1.670 & 0.095 \\
\hline Bridging & 0.496 & 0.056 & 0.587 & 8.790 & 0.000 \\
\hline Linking & 0.142 & 0.066 & 0.233 & 2.130 & 0.034 \\
\hline
\end{tabular}


From the results on Table $8, r=0.275$ indicating that there is a weak positive correlation between social capital and performance of food security projects. The adjusted R2 $=0.2055$ implying that social capital explains $20.55 \%$ of the variations in performance of food security projects while the other percentage is explained by other variables other than social capital. Bonding, Bridging and Linking were the individual parameters of social capital. Individually all of them were statistically significant at $10 \%$ and $5 \%$ level of significance since their $p$ values were less than 0.1 and 0.05 . For bonding, $\mathrm{p}=0.095<0.1$, bridging $\mathrm{p}=0.000<0.05$ and linking $\mathrm{p}=0.034<0.05$.

For the Beta coefficients, bonding 0.102 was statistically significant since $p=0.095<0.1$. The implication for this was that bonding, statistically had a positive influence on performance of food security projects. Bridging had a beta coefficient of 0.496 and it was statistically significant since $p$ $=0.000<0.05$. The implication for this was that bridging as an indicator of social capital had a statistically positive influence on performance of food security projects. Linking had a beta coefficient of 0.142 which was statistically significant at $5 \%$ level of significance since $\mathrm{p}=$ $0.034<0.05$. An implication for this was that linking, as an indicator of social capital had a positive influence on performance of food security projects. In terms of comparison, bridging had the strongest influence (0.496), followed by linking (0.142) then bonding (0.102).

In terms of the composite indicator of social capital, the overall $F$ statistic of $F=37.12$ was statistically significant since $\mathrm{p}=0.000<0.05$. This was an indication that there was a statistical significant relationship between social capital and performance of food security projects. In respect of this, the null hypothesis that was being tested was rejected and conclude that social capital has a significant influence on the performance of food security projects in Loima Sub County. This is illustrated by the following summative equation and summarized in Table 9.

$$
\mathrm{Y}=3.633+0.102 \mathrm{BO}+0.496 \mathrm{BR}+0.142 \mathrm{LN}
$$

Where,

$\mathrm{Y}=$ Performance of food Scurity Projects

$\mathrm{BO}=$ Bonding

$\mathrm{BR}=$ Bridging

LN = Linking

Table 9: Summary of Hypothesis Testing - Results

\begin{tabular}{|c|c|c|c|c|}
\hline Objective & Hypothesis & Results & Resulting Model & Conclusion \\
\hline To establish the & Social capital has & & & \\
extent to which & significant & & $\mathrm{Y}=3.816+$ & \\
social capital & influence on the & Adjusted & $0.300 \mathrm{BO}+$ & Reject the null \\
influences & performance & $\mathrm{R} 2=0.2055$ & $0.532 \mathrm{BR}+$ & hypothesis \\
performance of & of food security & $\mathrm{F}=37.12$ & & \\
food security & projects in & $\mathrm{P}=0.000<0.005$ & & \\
projects in & Turkana County, & & & \\
Turkana County, & Kenya. & & & \\
Kenya. & & & & \\
& & & & \\
\hline
\end{tabular}


Mark, E. N., Mulwa, A. S., \& Kyalo, D. N. (2020) Significance of Social Capital in Community Resilience and Performance of Food Security Project in Loima Sub-County, Turkana County, Kenya. Advances in Social Sciences Research Journal, 7(5) 589-606.

\section{DISCUSSION OF FINDINGS}

The study results show that social capital has a significant influence on the performance of food security projects in Loima Sub County. However, there existed weak positive correlation between social capital and performance of food security projects which is a clear indication that some forms of social capital had more influence on food security than other forms of social capital. This equally means that although social capital influenced performance of food security other capital such as human capital as well as natural capitals also played an important role on food security in the study area.

Bonding capital was the most significant social capital in the study area followed by bridging social capital. Linking social capital was weak in Loima Sub-County. The strong bonding and bridging social capital were limited to enhancing short term absorptive and to less extend adaptive capacity of community. The weak linking capital is attributed to long-term marginalization of the study area by successive regimes in Kenya, which impended long-term transformation of the community to prevent impending disaster impacts. Drought vulnerability in the study area was aggravated by deeper inequalities in access to public goods and services. Food security was still a challenge in the study area as households depended on food aid while existing food security projects were shortterm.

The weak linking capital in the study area is supported by Aukot (2003) who in his assessment of socioeconomic conditions in Turkana county noted that marginalization of the Turkana is attributed to the colonial sole objective of exploiting rich fertile agricultural land with no plan for arid areas like Turkana. According to Aukot (2003) after independence, marginalization of the Turkana continued through the sessional paper 10 of 1965 on Africa socialism. The policy ensured that though marginalized and needed more resources to be at par with other regions, they were put at the bottom of government priority.

The current Global Report on Food Crises (2020) also recognized the informal nature of the pastoralist communities in Kenya due to lack of government support. This means that pastoralists, who are already vulnerable, are forced to operate without formal finance, credit or legal mechanisms to protect them. Due to their location at the periphery of the Country, border areas often attract low national policy attention or investment, thereby gradually degenerating into poverty and high levels of vulnerability.

The findings of this study are in agreement with Fox (1996) whom on his study on the political construction of social capital in rural Mexico found that both bridging and linking social capitals were important in ensuring improved food security, as opposed to bonding social capital. Cleaver (2005) on his publication on the inequality of social capital and the reproduction of chronic poverty supports Fox's findings. Narayan and Pritchett (1999) and Grootaert and Narayan (2004) in their studies in Tanzania and Bolivia respectively equally found positive associations between household welfare and social capital (mainly bridging and linking levels).

However, in trying to understand how social capital work in poor communities Saegert et al., (2001), found that bridging social capital needs to be supported by bonding social capital, especially of the cognitive type, since norms of trust and helpfulness in a community potentially facilitate 
cooperation and coordination that renders benefits from bridging and linking social capital more useful to members.

In their study on social capital dimensions in household food security interventions in rural Uganda, Haroon et al., (2018) found that although social capital was important in enhancing food security, social capital by itself is insufficient to address food insecurity challenges. They recommended that social capital should be complemented with human capital enhancement.

\section{CONCLUSIONS}

Based on the findings, the study concludes that social capital has an influence on performance of food security projects in Loima Sub County. More specifically, the following conclusions are made:

a) Bonding and bridging capital were more significant in the study area, they were limited to enhancing short term absorptive and to less extend adaptive capacity of community. They helped to curb short-term food insecurity especially during drought as manifested through communal sharing.

b) Linking social capital was low in the study area, the low external engagement coupled with lack of resources and increased number of poor people in the study area was an impediment to the realization of food security.

c) Drought vulnerability in the study area was aggravated by deeper inequalities in access to public goods and services.

\section{RECOMMENDATIONS}

Based on the findings of the study, the following recommendations were made:

a) With the study findings clearly showing weak linkage on the vertical relations between the community and state and non-state actors, more policies and strategies need to be formulated with active participation of the local people for clear priority settings to reverse the longstanding marginalization which underpin current levels of vulnerability and food insecurity.

b) The study findings indicated a strong bonding and bridging social capital in the study area, in order to gain legitimacy development practitioners should build on existing community social capital and local-level institutions, including community groups, and build their capacity and their ability to respond to uncertainty.

c) The study findings indicated performance of food security improved with increase in bonding, bridging and linking social capital, there is therefore need to enhance community resilience by focusing on the social capital along the food systems through the development of integrated solutions along the food production, transformation and consumption chain.

\section{References}

[1]. Action Aid (2016): Resilience Handbook - A Guide to Integrated Resilience Programming. http://www.actionaid.org/sites/files/actionaid/2016_reslience_handbook.pdf.

[2]. Agrawal, A., Kononen, M, and Perrin, N. (2009). The role of local institutions in adaptation to climate change. Paper no. 118: Social development working papers.

[3]. Akçomak, S. (2009). Bridges in social capital: a review of the definitions and the social capital of social capital researchers, Working Paper \#2009-002, United Nations University, Maastricht.

[4]. Aldrich, D. P. (2010). Separate and Unequal: Post-Tsunami Aid Distribution in Southern India. Social Science Quarterly, 1369-1389. 
Mark, E. N., Mulwa, A. S., \& Kyalo, D. N. (2020) Significance of Social Capital in Community Resilience and Performance of Food Security Project in Loima Sub-County, Turkana County, Kenya. Advances in Social Sciences Research Journal, 7(5) 589-606.

[5]. Aldrich, D. P. (2012). Social, not Physical, Infrastructure: The Critical Role of Civil Society After the 1923 Tokyo Earthquake. Disasters, 398-419.

[6]. Aukot, E., (2003). It is better to be a refugee than a Turkana in Kakuma: Revisiting the relationship between the host and refugees in Kenya. Refuge, Vol. 21, Number 3.

[7]. Béné et al. (2017). Squaring the Circle: Reconciling the Need for Rigor with the Reality on theGroundinResilienceImpactAssessment.https://www.sciencedirect.com/science/article/pii/S0305750X17301286.

[8]. Burkley, A. L., Brown, K., Holben, D. H., Shubrook, J. H., \& Schwartz, F. L. (2011). Adult Food Security and Social Capital. among Patients Using Free and Fee-for Service Diabetes Clinics in Rural, Appalachian Ohio. Journal of the American Dietetic Association, A100.

[9]. Cleaver, F. (2005). The inequality of social capital and the reproduction of chronic poverty. World Development, 33: 893-906.

[10]. Cutter et al. (2008): A place-based model for understanding community resilience to natural disasters. https://www.sciencedirect.com/science/article/abs/pii/S0959378008000666.

[11]. Devereux, S., and Getu, M. (2013). The conceptualization and status of informal and formal social protection in sub-Saharan Africa. Organisation for Social Research in Eastern and Southern Africa.

[12].Di Gregorio, M., Hagedorn, K., Kiri, M., Korf, B., McCarthy, N., Meinzen-Dick, R., Swallow, B., Mwangi, E., and Markelova,H., (2012). "Property Rights and Collective Action for Poverty Reduction: A Framework forAnalysis." In Collective Action and Property Rights for Poverty Reduction: Insights from Africa and Asia.

[13]. Edwards, B. \& Foley, M. (1998). Social capital and the political economy of our discontent. American Behavioral Scientist, 40(5), 669-678.

[14]. Flora, C.B., Flora, J.L., Fey, S., (2004). Rural communities: legacy and change. West view Press, Boulder, CO.

[15]. Food and Agriculture Organization. (2000). The state of food insecurity in the world. Rome, Italy: FAO.

[16. Fox, J. (1996). How does civil society thicken? The political construction of social capital in rural Mexico. World Development, 24, 1089-1103.

[17]. Global Report on Food Crises (2020). Joint analysis for better decisions. Food Security Information Network publication.

[18]. Grootaert, C. and Narayan, D. 2004. Local institutions, poverty and household welfare in Bolivia. World Development, 32, 1179-1198.

[19]. Haroon, S., Mazur, R.E., and Cornelia, B.F. (2018). Social capital dimensions in household food security interventions: implications for rural Uganda. Agriculture and Human values 35,117- 129 (2018).

[20]. Heale, R., and Twycross, A. (2015). Validity and reliability in quantitative studies. Evidence- based nursing, ebnurs-2015.

[21]. Hoddinott, J., S. Dercon, and P. Krishnan. (2009). “Networks and Informal Mutual Support in Ethiopian Villages: A Description." In Institutional Economics Perspectives on African Agricultural Development.

[22]. Holben, D.A. (2002). An overview of food security and its measurement. Nutrition Today, 37(4), 156-163.

[23]. Hunt, W., Vanclay, F., Birch, C., Coutts, J., \& Flittner, N. (2011). Agicultural Extention: Building Capacity and Resilience in Rural Industries and Communities. Rural Sociology, 112-127.

[24]. International Livestock Research Institute (ILRI, 2009). Expanding livestock insurance Coverage in Turkana County.

[25]. Kareithi, J.N. (2010), "Declining social capital and vulnerability to livelihood risks in Turkana district, Kenya". Journal of the Institute of African Studies, Vol. 11, pp. 33-46.

[26]. Keck, M., and P. Sakdapolrak. 2013. "What Is Social Resilience? Lessons Learned and the Way Forward." Erdkunde, 67 (1): 5-19. 
[27]. Keenan, D.P., Olson, C., Hersey. J.C. and Parmer S.M. (2001). Measures of food insecurity/security. Journal of Nutrition Education, 33, 49-58.

[28]. Kennedy, E. and Haddad, L. (1992). Food security and nutrition, 1971-91: lessons learned and future priorities. Food Policy 17(1), 2-6.

[29]. Kiboro, C.N. (2018). Impact of social capital on the resettlement of internally displaced persons: The case of Nakuru and Uasin Gishu Counties Kenya, College of Humanities and Social Sciences, University of Nairobi.

[30]. Mertens, D. M. (2014). Research and evaluation in education and psychology: Integrating diversity with quantitative, qualitative, and mixed methods. Sage publications.

[31]. Morrow, S. E. (2013). Social capital, food security, and resource utilization in a low income population. Ann Arbor, MI: Masters Abstracts International.

[32]. Morton, L. W., Bitto, E. A., Oakland, M. J., and Mary, S. (2008). Accessing Food Resources: Rural and Urban Patterns of Giving and Getting Food. Agriculture and Human Values, 107-120.

[33]. Moser, C. (2010). Pro-poor adaptation to climate change in urban centers: Case studies of vulnerability and resilience in Kenya and Nicaragua, 54947-GLB.

[34. Nakagawa, Y., and R. Shaw. (2004). "Social Capital: A Missing Link to Disaster Recovery.” International Journal of Mass Emergencies and Disasters, 22 (1): 5-34.

[35]. Narayan, D., Pritchett, L. (1999). Cents and sociability: household income and social capital in rural Tanzania. Econ. Dev. and Cult. Change 47, 871-897.

[36]. Njuki, J. M., M. T. Mapila, S. Zingore, and R. Delve. (2008). “The Dynamics of Social Capital in Influencing Use of Soil Management Options in the Chinyanja Triangle of Southern Africa." Ecology and Society, 13 (2): 9.

[37]. Omolo, N. and Mafongoya, P. (2019). "Gender, social capital and adaptive capacity to climate variability: A case of pastoralists in arid and semi-arid regions in Kenya", International Journal of Climate Change Strategies and Management, Vol. 11 No. 5, pp. 744-758.

[38]. Omondi, D.O., (2013). Why Turkana people must benefit from the oil and water discoveries in their native land. Published on the Kenyan Standard Newspaper of 1st October, 2013.

[39]. OXFAM (2017). The Future is a Choice: OXFAM Framework and Guidance for Resilient Development. https://policy-practice.oxfam.org.uk/publications/the-future-is-a-choice-the-oxfam-framework-andguidance-forresilient-developme-604990.

[40]. Pretty, J. \& Ward, H. (2001). Social capital and the environment. World Development, 29(2), 209-227.

[41]. Putnam, R. (2000). Bowling Alone: The Collapse and Revival of American Community. New York, NY: Simon \& Schuster.

[42]. Rose, R. (2000). How much does social capital add to individual health? A survey study of Russians. Social Science \& Medicine, 51(9), 1421-1435.

[43]. Rutland, A., and Killen, M. (2015). A developmental science approach to reducing prejudice and social exclusion: Intergroup processes, social-cognitive development, and moral reasoning. Social Issues and Policy Review, 9(1), 121154.

[44]. Saegert, S., Thompson, J., Warren, M. (2001). Social capital and poor communities, Russen Sage Foundation, New York.

[45]. Shackleton, S., Ziervogel, G., Sallu, S., Gill, T., and Tschakert, P. (2015). Why is socially-just climate change adaptation in sub-Saharan Africa so challenging? A review of barriers identified from empirical cases. Wiley Interdisciplinary Reviews: Climate Change, 6(3), 321- 344.

[46]. Tajfel, H., Turner,J.C., Austin,W.G., and Worchel,S. (1979). An integrative theory of intergroup conflict. Organizational identity: A reader, 56-65.

[47]. Thomas, J. R., Silverman, S., and Nelson, J. (2015). Research methods in physical activity, 7E. Human kinetics. 
Mark, E. N., Mulwa, A. S., \& Kyalo, D. N. (2020) Significance of Social Capital in Community Resilience and Performance of Food Security Project in Loima Sub-County, Turkana County, Kenya. Advances in Social Sciences Research Journal, 7(5) 589-606.

[48]. Tumbo, S. D., K. D. Mutabazi, K. F. G. Masuki, F. B. Rwehumbiza, H. F. Mahoo, S. J. Nindi, and J. G. Mowo. (2013). "Social Capital and Diffusion of Water System Innovations in the Makanya Watershed, Tanzania." The Journal of Socioeconomics 43:24-36.

[49]. United States Agency for International Development Center for Resilience. (2018). Economics of resilience to drought: Kenya analysis.

https://agrilinks.org/sites/default/files/kenya_economics_of_resilience_final_jan_4_2018_-_branded.pdf.

[50]. Uphoff, N. Wijayaratna, C.M., (2000). Demonstrated benefits from social capital: the productivity of farmer organizations in Gal Oya, Sri Lanka. World Development, 28, 1875-1890.

[51]. Watson,D.J., and Bisbergen, J.V. Livestock Market access and opportunities in Turkana Kenya. ILRI research report 3, 106, Nairobi, Kenya. 